The Social Sciences 14 (10): 346-355, 2019

ISSN: $1818-5800$

(C) Medwell Journals, 2019

\title{
Early High, Early Out? Marijuana Consumption During Youth and Educational Outcomes
}

\author{
Donata Bessey \\ East Asia International College, Yonsei University, Yonseidae-gil 1, \\ 220-710 Wonju, South Korea
}

\begin{abstract}
I analyze the impact of timing of onset of marijuana use in youth on educational outcomes, distinguishing between general and vocational education. Using the Swiss Health Survey (2002) and a generalized ordered logit model for the estimations, I find some evidence for harmful effects of early marijuana consumption on educational success. Respondents who started to use marijuana before age 15 are significantly less likely to have at least a general secondary-level education, general tertiary-level and vocational secondary-level education. Those who started to use marijuana between age 16 and 18 are more likely to have a secondary or tertiary-level general education than those who never used the drug. The effects differ between those in general and those in vocational education, suggesting that the differences in institutional setting and time horizon between the two different educational tracks might lead to different effects on educational outcomes.
\end{abstract}

Key words: Risky behavior, production of human capital, vocational education, marijuana consumption, educational, horizon

\section{INTRODUCTION}

The use of marijuana has become a common phenomenon among youths in many countries and many countries have recently seen liberalizations in laws regarding marijuana use (source). According to the European School Survey Project on Alcohol and other Drug's 2015 report, about $30 \%$ of 16 years old students in more than 30 European countries had used marijuana at some point in their life (Anonymoous, 2015). The short-term effects of risky behaviors such as marijuana use are immediately clear and there is additional evidence on its long-term harmful consequences. Medical research has shown adverse effects of regular and prolonged marijuana and alcohol use on cognitive ability, especially on learning and memory of adults (Grant et al., 2003). As the adolescent brain might be more vulnerable to possible adverse effects of marijuana use than the adult brain, an analysis of the effects of age of onset of use during adolescence on educational outcomes should be an important research question.

In this study, I analyze the impact of age of onset of marijuana use in adolescence on educational outcomes in Switzerland. I compare its effects for students in general and in vocational education. Previous economic research focused in most cases on a specific subsample of the population such as high school students on relatively short-term consequences for outcomes such as grades and tried in most cases to analyze the impact of a risky behavior at any point in time during youth on educational outcomes. It has shown inconclusive results and is in general complicated by difficulties to establish that the results are indeed driven by a causal relationship. Pacula et al. (2003) use the national education longitudinal study and a differences-in-differences approach and find that marijuana use in high school does not seem to have an impact on results in standardized test scores, except for the scores in mathematics. Register et al. (2001), however, use the National Longitudinal Study of Youth and two-stage least squares estimation and find that marijuana use as well as use of other drugs reduce educational attainment by about 1 year. Roebuck et al. (2004) use two waves of the National Household Surveys on Drug Abuse and find that chronic marijuana use (defined as using the drug weekly or more frequently) seems to be the dominant factor for the relationship that they find between marijuana use and high school dropout probability and truancy. Marijuana users are found to be both more likely to dropout and to be truant. Ours and Williams (2009) use an Australian data set and duration model identification approaches in order to assess the causal impact of the timing of marijuana initiation on educational attainment. They find that earlier initiation into cannabis use leads to a significant reduction of years of schooling and that this effect is larger for females. McCaffrey et al. (2010), however, use a panel data set on students in South Dakota, adjusting for pre-existing differences in student's characteristics before most of them start marijuana consumption and find that the positive relationship between marijuana use and high school dropout is "unlikely to be due to its adverse effects on cognition" but instead likely to be due to parental and peer influences. Bessey (2010) analyzes the effects of age of onset of marijuana use on labor market and educational outcomes but does not distinguish between general and vocational education and finds little evidence for harmful effects. 
In this study, I take a slightly different approach. First of all, I analyze a representative sample of the population and compare the effects of early marijuana initiation for students in vocational education to those in general education as these two systems are characterized by different institutional settings and time horizons and might, therefore, lead to different effects of marijuana consumption during youth on educational outcomes. Switzerland is one of the few countries worldwide to have a well-developed vocational education system including tertiary-level vocational degrees and is therefore a natural candidate country to analyze this research question. Second, I take a longer-term perspective with respect to outcomes and measure educational outcomes as having graduated from secondary-level or tertiary-level education instead of analyzing the impact of marijuana consumption on years of schooling for two reasons. The first one is that there is considerable evidence on "sheepskin effects", i.e., the fact that there are wage increases above what would normally be attributed to the extra year of education for numbers of years of education that usually correspond to the completion of a degree (Hungerford and Solon, 1987). The second reason is that having earned a degree is the prerequisite for many further education possibilities and therefore matters much more than years of education completed. Finally and similarly to Ours and Williams (2009), I explicitly focus on the age of onset of marijuana use. It might be the case, for example, that early initiation into marijuana use is harmful while later initiation has less severe effects. I test if there are more or less detrimental periods with respect to age of initiation of marijuana use and their respective impact on educational outcomes of the individual in both general and vocational education.

Results show several novel findings. First of all, estimating a more flexible generalized ordered logit instead of an ordered logit model reveals that there are important differences between secondary and tertiary education that cannot be uncovered when estimating an ordered logit model. Secondly, there are important differences between vocational and general education. Having started to use marijuana before age 15 significantly lowers the probability of having a secondary and tertiary-level general education and a secondary-level vocational education. Having started to use between age 16 and 18, quite surprisingly, significantly increases the probability of having a secondary and tertiary-level general education. Comparing predicted probabilities for those in vocational and those in general education, I also find that there are indeed differences between the two groups, suggesting that the effects of early onset of marijuana use differ between educational tracks.

The remainder of this study is organized as follows. Part 2 briefly describes relevant features of general and vocational education in Switzerland, introduces the data set and provides descriptive statistics and outlines the estimation strategy. Part 4 presents the results and part 5 discusses and concludes.

\section{MATERIALS AND METHODS}

In the following sections, I give a brief overview of the Swiss educational system, followed by a description of the data set used for the empirical analysis and an outline of the estimation strategy.

\section{Institutional background; General and vocational} education in Switzerland: Switzerland, along with the other German-speaking countries, the Netherlands, Denmark and Sweden is one of the few countries worldwide to have a well-developed vocational education system including tertiary-level vocational degrees and is therefore, a natural candidate country to analyze our research question. In the following section, I briefly describe some key characteristics of the Swiss educational system that are of particular importance for this study. For a more detailed description and analysis, see for example Schweizerische Koordinationsstelle für Bildungs for schung (2014).

In general, education is within the responsibility of the 26 Swiss cantons, so, there might be slight differences between the cantons. However, they all share some similar characteristics that we will outline here. In most cantons, students are tracked on ability after 6 years of primary schooling, leading to ability-based grouping in the 3 years of lower secondary schooling. Compulsory schooling ends after those 9 years and students who want to continue their education now can choose between general schooling baccalaureate schools (Gymnasiale Maturitätsschule), preparing students to enter university), upper secondary specialized schools (Fachmittelschule), preparing students to enter professional education and training colleges) and apprenticeship training consisting of both schooling and practical training in a firm. The former two types of schooling take 3-4 years to graduation, the apprenticeships take between 2 and 4 years and are the only type of training that contains considerable amounts of practical, firm-based training. In the following empirical analysis, those who graduated from lower secondary schooling are labeled as having "compulsory schooling", those who graduated from baccalaureate schools are labeled as having "secondary general education" and those who graduated from either upper secondary specialized schools or apprenticeship training are labeled as having "secondary vocational education".

At the tertiary educational level, there are universities, universities of applied sciences (Fachhochschule) and teacher training colleges (Pädagogische Hochschule), professional education and training colleges (Hohere 
Fachschule) and the possibility to become a master craftsman by preparing for the corresponding federal exams (Eidgenossische Berufs-und Fachprufungen). Some professional education and training colleges require relevant professional experience. In their part-time version, students work and study, in their full-time versions, students have to take mandatory internships in their chosen occupation. Hence, they also contain sizeable amounts of practical training. All tertiary educational programs take 3 years to graduate with a bachelor's degree, except for the master craftsman preparation. Here, most examinations require a certain number of years of professional experience in the corresponding occupation. There are preparation classes for the exams but participation in them is not mandatory. Finally, examinees prepare for those exams while working full-time while all other tertiary level education programs in Switzerland are either full-time or part-time education programs, hence, this is the second type of tertiary-level education program that contains considerable amounts of practical, firm-based training. In the following empirical analysis, those who graduated from universities, universities of applied sciences or teacher training colleges are labeled as having "tertiary general education" and those who graduated from the remaining two types of programs are labeled as having "tertiary vocational education".

As this brief overview about vocational and general education programs in Switzerland has shown, there are considerable differences in terms of institutions, duration and contents (theoretical/school-based vs. practical/firm based training). It might be the case that those differences lead to different effects of the age of onset of marijuana consumption on educational outcomes. For example, the longer time horizon and less formalized setting of the tertiary vocational education programs, compared to general ones, might lead to less harm from early marijuana consumption. One could also imagine that early marijuana consumption might be less harmful in the tertiary educational education programs because most students usually do not enter the more academically oriented baccalaureate schools but enter apprenticeship training with its more applied nature directly after lower secondary schooling and that marijuana consumption might have different effects there. In the empirical analysis, I will investigate whether this is the case.

Data set and descriptive statistics: My empirical analysis is based on the 2002 Swiss Health Survey (Schweizerische Gesundheitsbefragung), a representative sample of the Swiss resident population. It is carried out every five years by the Swiss Federal Statistical Office (Bundesamt für Statistik) in order to gain insights on the health status of Switzerland's population age 15 and older. Questions include items on physical, mental and social health status living conditions, health-related behaviors but also items such as respondent's level of education, employment and household income. The survey contains detailed questions on marijuana (and other drug) consumption and the age of onset of consumption, my regressors of interest and on educational outcomes, my dependent variable. However, as its focus is on health, it contains little information on variables that might matter for educational success such as parental education, parental wealth or ability. I discuss in the estimation section how I deal with this shortcoming of the data set. The survey consists of two parts, the first one being a computer-assisted telephone interview, the second one being a questionnaire that was sent out to participants of the phone interview. The total sample size is $\mathrm{n}=$ 13.134. However, I restricted the sample to respondents who have indicated that they are not in full-time training anymore, meaning that they are likely to have completed their education because I am interested in the determinants of the probabilities of having finished an educational degree. The restricted sample still consists of $\mathrm{n}=11.049$ individuals (Table 1 ).

The lifetime prevalence of marijuana use in the entire sample is $19.12 \%$. The $2.17 \%$ of individuals started to smoke marijuana before they turned 15 and another $8.64 \%$ started between age 16 and 18 . The rest started to use marijuana later in life (Table 2).

In the entire sample, almost $10 \%$ of respondents have compulsory schooling or less, about $70 \%$ have a secondary-level education and almost $20 \%$ have a tertiary-level education in either general or vocational education. Secondary general education corresponds to upper secondary education, i.e., a baccalaureate school graduation, secondary vocational education corresponds to a completed apprenticeship or graduation from an upper secondary specialized school, tertiary general education corresponds to a university degree, a degree from a university of applied sciences or a teacher training college and tertiary vocational education corresponds to a graduate from professional education and training colleges or federal exams for master craftsmen. A look at

\begin{tabular}{lcr}
\multicolumn{4}{l}{ Table 1: Age of onset of marijuana use } \\
\hline Age & Percentage & No. of users \\
\hline Never & 80.88 & 8944 \\
Under 15 & 2.17 & 239 \\
Between 16 and 18 & 8.64 & 951 \\
Later in life & 8.31 & 915 \\
Sum & 100.00 & 11049 \\
\hline
\end{tabular}

Table 2: Educational outcomes by age of onset of marijuana use

\begin{tabular}{llllll}
\hline & & Under & Between & Later & Entire \\
Educational outcomes life & Never & 15 & $16-18$ & sample \\
\hline Compulsory and less & $10.91 \%$ & $10.88 \%$ & $5.89 \%$ & $4.59 \%$ & $9.95 \%$ \\
Secondary general & $5.20 \%$ & $5.86 \%$ & $6.20 \%$ & $6.12 \%$ & $5.38 \%$ \\
Secondary vocational & $65.80 \%$ & $65.27 \%$ & $64.65 \%$ & $59.45 \%$ & $65.16 \%$ \\
Tertiary general & $6.94 \%$ & $5.86 \%$ & $10.94 \%$ & $14.97 \%$ & $7.93 \%$ \\
Tertiary vocational & $11.15 \%$ & $12.13 \%$ & $12.41 \%$ & $14.86 \%$ & $11.58 \%$ \\
n & 8944 & 239 & 951 & 915 & 11049 \\
\hline
\end{tabular}


educational outcomes by the age of onset of marijuana use reveals a higher percentage of individuals with only compulsory schooling among respondents who started before they turned 15 . However, among those who started between age 16 and 18, the number is lower than in the entire sample.

Estimation strategy: Instead of analyzing the effect of marijuana use during any point in adolescence on educational outcomes, I focus on the timing of marijuana initiation and distinguish between two age groups: initiation under age 15 and initiation between age 16 and 18. Those age groups correspond to the ages at which students typically graduate from lower secondary education and higher secondary education, respectively. Initiation during these time periods may lead to lowered probabilities of graduating from the respective levels of education. In addition to analyzing the effects of age of onset of marijuana use on educational success, I also want to compare the effects for students in vocational education vs. general education. To measure educational success, I have information on respondent's highest level of schooling (compulsory, secondary or tertiary) with additional information whether schooling was finished in vocational or in general education. This is ordered information but it is not clear what the order is between general and vocational education, i.e., if a secondary vocational degree represents a higher value than a secondary general education degree or vice versa. One possibility to analyze this type of data would be a multivariate model but this ignores the ordered nature of the dependent variable and therefore would not be an efficient estimation approach. Instead, I employ an ordered logit model that uses the ordering information and first test whether there actually are differences between the two groups (vocational vs. general education) by estimating a model where the dependent variable is simply information on the respondent's highest level of education (compulsory or less, secondary, tertiary) and adding a dummy variable that takes the value of 1 if it was completed in vocational education. If the estimated coefficient on this dummy variable is statistically significant, I can take this as evidence that there are indeed differences between those in vocational and those in general education and compare the effects of age of onset of marijuana use on educational success between the two groups in a second step.

Comparing estimated parameters between groups (such as vocational versus general education) in nonlinear models is less straightforward than in linear models because of the inherent identification problem in these models and the resulting fact that the size of the estimated coefficients will be confounded with residual variation in nonlinear models (Allison, 1999). He suggests a possibility to compare estimation coefficients between groups but his method needs the assumption that regression coefficients for some variables are identical across groups. Long (2009) suggests an alternative way to compare effects across groups by using predicted probabilities. As his approach does not hinge on the assumption of some identical parameters and can easily be adapted for ordered nonlinear models, I follow his approach and compare predicted probabilities that are unaffected by residual variation.

One possible problem with the use of an ordered model is that it might be overly restrictive because it implicitly imposes a parallel regression assumption (sometimes also called parallel lines or proportional odds assumption). I use likelihood ratio tests to formally test for the equality of parameter coefficients $\beta_{1}=\beta_{2}$ and find that the null hypothesis of equal slope parameters is rejected for all equations that I estimate. Test statistics are presented in Table 3. Therefore, I estimate the more

Table 3: Estimated coefficients, generalized ordered logit models

\begin{tabular}{|c|c|c|c|c|c|c|}
\hline Estimated coefficients & Entire (sec.) & Entire, tert. & General (sec.) & General, tert. & Vocational (sec.) & Vocational, tert. \\
\hline 1 = vocational education & $\begin{array}{l}24.833 \\
{[3,464.625]}\end{array}$ & $\begin{array}{l}-1.255^{* * *} \\
{[0.057]}\end{array}$ & & & & \\
\hline $1=$ marijuana under 15 & $\begin{array}{l}-0.346 \\
{[0.262]}\end{array}$ & $\begin{array}{l}-0.184 \\
{[0.183]}\end{array}$ & $\begin{array}{l}-0.524^{*} \\
{[0.312]}\end{array}$ & $\begin{array}{l}-0.603 * \\
{[0.348]}\end{array}$ & $\begin{array}{l}-0.470^{* *} \\
{[0.227]}\end{array}$ & $\begin{array}{l}-0.063 \\
{[0.211]}\end{array}$ \\
\hline $1=$ marijuana $16-18$ & $\begin{array}{l}0.232 \\
{[0.159]}\end{array}$ & $\begin{array}{l}0.051 \\
{[0.089]}\end{array}$ & $\begin{array}{l}0.381 * * \\
{[0.175]}\end{array}$ & $\begin{array}{l}0.345^{* *} \\
{[0.162]}\end{array}$ & $\begin{array}{l}0.093 \\
{[0.152]}\end{array}$ & $\begin{array}{l}-0.059 \\
{[0.111]}\end{array}$ \\
\hline Age & $\begin{array}{l}0.138^{* * *} \\
{[0.024]}\end{array}$ & $\begin{array}{l}0.186^{* * * *} \\
{[0.019]}\end{array}$ & $\begin{array}{l}0.174 * * * \\
{[0.028]}\end{array}$ & $\begin{array}{l}0.261 * * * \\
{[0.035]}\end{array}$ & $\begin{array}{l}0.073^{* * * *} \\
{[0.023]}\end{array}$ & $\begin{array}{l}0.153^{* * * *} \\
{[0.023]}\end{array}$ \\
\hline Age squared & $\begin{array}{l}-0.002 * * * \\
{[0.000]}\end{array}$ & $\begin{array}{l}-0.002 * * * \\
{[0.000]}\end{array}$ & $\begin{array}{l}-0.002^{* * *} \\
{[0.000]}\end{array}$ & $\begin{array}{l}-0.003 * * * \\
{[0.000]}\end{array}$ & $\begin{array}{l}-0.001 * * * \\
{[0.000]}\end{array}$ & $\begin{array}{l}-0.002^{* * *} \\
{[0.000]}\end{array}$ \\
\hline $1=$ female & $\begin{array}{l}-0.874^{* * *} \\
{[0.077]}\end{array}$ & $\begin{array}{l}-1.150^{* * *} \\
{[0.054]}\end{array}$ & $\begin{array}{l}-0.753^{* * *} \\
{[0.091]}\end{array}$ & $\begin{array}{l}-1.008 * * * \\
{[0.092]}\end{array}$ & $\begin{array}{l}-0.756^{* * *} \\
{[0.073]}\end{array}$ & $\begin{array}{l}-1.269 * * * \\
{[0.067]}\end{array}$ \\
\hline Happy childhood & $\begin{array}{l}0.365^{* * *} \\
{[0.037]}\end{array}$ & $\begin{array}{l}0.198 * * * \\
{[0.031]}\end{array}$ & $\begin{array}{l}0.491 * * * \\
{[0.050]}\end{array}$ & $\begin{array}{l}0.354 * * * \\
{[0.052]}\end{array}$ & $\begin{array}{l}0.324^{* * * *} \\
{[0.035]}\end{array}$ & $\begin{array}{l}0.140 * * * \\
{[0.038]}\end{array}$ \\
\hline 1 = Swiss citizenship & $\begin{array}{l}1.076^{* * *} \\
{[0.134]}\end{array}$ & $\begin{array}{l}0.778^{* * * *} \\
{[0.108]}\end{array}$ & $\begin{array}{l}1.350 * * * \\
{[0.153]}\end{array}$ & $\begin{array}{l}1.144 * * * \\
{[0.155]}\end{array}$ & $\begin{array}{l}1.419 * * * \\
{[0.126]}\end{array}$ & $\begin{array}{l}0.597 * * * \\
{[0.152]}\end{array}$ \\
\hline 1 = Swiss father & $\begin{array}{l}-0.055 \\
{[0.173]}\end{array}$ & $\begin{array}{l}-0.142 \\
{[0.107]}\end{array}$ & $\begin{array}{l}-0.194 \\
{[0.198]}\end{array}$ & $\begin{array}{l}-0.409 * * \\
{[0.194]}\end{array}$ & $\begin{array}{l}0.292^{*} \\
{[0.149]}\end{array}$ & $\begin{array}{l}0.026 \\
{[0.134]}\end{array}$ \\
\hline
\end{tabular}


The Soc. Sci., 14 (10): 346-355, 2019

\begin{tabular}{|c|c|c|c|c|c|c|}
\hline Estimated coefficients & Entire (sec.) & Entire, tert. & General (sec.) & General, tert. & Vocational (sec.) & Vocational, tert. \\
\hline $1=$ Swiss mother & $\begin{array}{l}-0.1 \\
{[0.170]}\end{array}$ & $\begin{array}{l}-0.132 \\
{[0.104]}\end{array}$ & $\begin{array}{l}-0.041 \\
{[0.197]}\end{array}$ & $\begin{array}{l}0.003 \\
{[0.191]}\end{array}$ & $\begin{array}{l}0.121 \\
{[0.148]}\end{array}$ & $\begin{array}{l}-0.122 \\
{[0.128]}\end{array}$ \\
\hline 1 = lives in Lake Geneva region & $\begin{array}{l}0.107 \\
{[0.125]}\end{array}$ & $\begin{array}{l}0.247 * * * \\
{[0.091]}\end{array}$ & $\begin{array}{l}0.368 * * \\
{[0.156]}\end{array}$ & $\begin{array}{l}0.590^{* * * *} \\
{[0.162]}\end{array}$ & $\begin{array}{l}-0.235^{*} \\
{[0.123]}\end{array}$ & $\begin{array}{l}0.021 \\
{[0.113]}\end{array}$ \\
\hline 1 = lives in Espace Mittelland & $\begin{array}{l}-0.039 \\
{[0.118]}\end{array}$ & $\begin{array}{l}-0.034 \\
{[0.084]}\end{array}$ & $\begin{array}{l}0.067 \\
{[0.147]}\end{array}$ & $\begin{array}{l}0.085 \\
{[0.158]}\end{array}$ & $\begin{array}{l}-0.113 \\
{[0.111]}\end{array}$ & $\begin{array}{l}-0.094 \\
{[0.098]}\end{array}$ \\
\hline $1=$ lives in Northwest & $\begin{array}{l}0.273 * \\
{[0.151]}\end{array}$ & $\begin{array}{l}0.056 \\
{[0.095]}\end{array}$ & $\begin{array}{l}0.529 * * * \\
{[0.178]}\end{array}$ & $\begin{array}{l}0.400 * * \\
{[0.179]}\end{array}$ & $\begin{array}{l}0.470 * * * \\
{[0.141]}\end{array}$ & $\begin{array}{l}-0.048 \\
{[0.113]}\end{array}$ \\
\hline 1 = lives in Zurich & $\begin{array}{l}0.12 \\
{[0.175]}\end{array}$ & $\begin{array}{l}0.075 \\
{[0.111]}\end{array}$ & $\begin{array}{l}0.251 \\
{[0.209]}\end{array}$ & $\begin{array}{l}0.202 \\
{[0.211]}\end{array}$ & $\begin{array}{l}0.422 * * \\
{[0.165]}\end{array}$ & $\begin{array}{l}0.095 \\
{[0.129]}\end{array}$ \\
\hline $1=$ lives in East & $\begin{array}{l}-0.014 \\
{[0.147]}\end{array}$ & $\begin{array}{l}-0.052 \\
{[0.098]}\end{array}$ & $\begin{array}{l}0.008 \\
{[0.182]}\end{array}$ & $\begin{array}{l}-0.136 \\
{[0.202]}\end{array}$ & $\begin{array}{l}0.226^{*} \\
{[0.134]}\end{array}$ & $\begin{array}{l}-0.036 \\
{[0.110]}\end{array}$ \\
\hline $1=$ lives in Ticino & $\begin{array}{l}0.26 \\
{[0.162]}\end{array}$ & $\begin{array}{l}-0.484^{* * *} \\
{[0.131]}\end{array}$ & $\begin{array}{l}0.461 * * \\
{[0.184]}\end{array}$ & $\begin{array}{l}-0.302 \\
{[0.207]}\end{array}$ & $\begin{array}{l}-0.256^{*} \\
{[0.147]}\end{array}$ & $\begin{array}{l}-0.579 * * * \\
{[0.173]}\end{array}$ \\
\hline $\begin{array}{l}1=\text { lives in mun. } \\
\text { betw. } 1000-1999 \text { inhabitants }\end{array}$ & $\begin{array}{l}0.036 \\
{[0.157]}\end{array}$ & $\begin{array}{l}0.03 \\
{[0.113]}\end{array}$ & $\begin{array}{l}-0.1 \\
{[0.186]}\end{array}$ & $\begin{array}{l}-0.28 \\
{[0.212]}\end{array}$ & $\begin{array}{l}-0.079 \\
{[0.139]}\end{array}$ & $\begin{array}{l}0.125 \\
{[0.132]}\end{array}$ \\
\hline $\begin{array}{l}1=\text { lives in mun. } \\
\text { betw. } 2000-4999 \text { inhabitants }\end{array}$ & $\begin{array}{l}-0.059 \\
{[0.136]}\end{array}$ & $\begin{array}{l}0.098 \\
{[0.099]}\end{array}$ & $\begin{array}{l}-0.13 \\
{[0.165]}\end{array}$ & $\begin{array}{l}-0.01 \\
{[0.180]}\end{array}$ & $\begin{array}{l}-0.058 \\
{[0.124]}\end{array}$ & $\begin{array}{l}0.125 \\
{[0.119]}\end{array}$ \\
\hline $\begin{array}{l}1=\text { lives in mun. } \\
\text { betw. } 5000-9999 \text { inhabitants }\end{array}$ & $\begin{array}{l}0.236 \\
{[0.148]}\end{array}$ & $\begin{array}{l}0.189 * \\
{[0.104]}\end{array}$ & $\begin{array}{l}0.195 \\
{[0.176]}\end{array}$ & $\begin{array}{l}0.065 \\
{[0.189]}\end{array}$ & $\begin{array}{l}0.270^{* *} \\
{[0.135]}\end{array}$ & $\begin{array}{l}0.236^{*} \\
{[0.124]}\end{array}$ \\
\hline 1 = lives in mun. & $0.312^{* *}$ & $0.195^{*}$ & $0.396^{* *}$ & $0.383^{* *}$ & 0.208 & 0.116 \\
\hline $\begin{array}{l}\text { betw. } 10000-19999 \text { inhabitants } \\
1=\text { lives in mun. }\end{array}$ & $\begin{array}{l}{[0.153]} \\
0.347 * *\end{array}$ & $\begin{array}{l}{[0.106]} \\
0.444^{* * *}\end{array}$ & $\begin{array}{l}{[0.178]} \\
0.464 * *\end{array}$ & $\begin{array}{l}{[0.189]} \\
0.587 * * *\end{array}$ & $\begin{array}{l}{[0.135]} \\
0.087\end{array}$ & $\begin{array}{l}{[0.128]} \\
0.331^{* *}\end{array}$ \\
\hline betw. 20000-49999 inhabitants & [0.159] & {$[0.116]$} & {$[0.189]$} & {$[0.197]$} & {$[0.150]$} & {$[0.145]$} \\
\hline $\begin{array}{l}1=\text { lives in mun. } \\
\text { betw. } 50000-99999 \text { inhabitants }\end{array}$ & $\begin{array}{l}0.475^{*} \\
{[0.259]}\end{array}$ & $\begin{array}{l}0.475^{* * *} \\
{[0.183]}\end{array}$ & $\begin{array}{l}0.567^{*} \\
{[0.309]}\end{array}$ & $\begin{array}{l}0.562 * \\
{[0.320]}\end{array}$ & $\begin{array}{l}0.012 \\
{[0.246]}\end{array}$ & $\begin{array}{l}0.435^{* *} \\
{[0.221]}\end{array}$ \\
\hline $\begin{array}{l}1=\text { lives in mun. } \\
\text { over } 100000 \text { inhabitants }\end{array}$ & $\begin{array}{l}0.632 * * * \\
{[0.173]}\end{array}$ & $\begin{array}{l}0.537 * * * \\
{[0.117]}\end{array}$ & $\begin{array}{l}0.928 * * * \\
{[0.199]}\end{array}$ & $\begin{array}{l}0.929 * * * \\
{[0.198]}\end{array}$ & $\begin{array}{l}0.345^{* *} \\
{[0.166]}\end{array}$ & $\begin{array}{l}0.21 \\
{[0.153]}\end{array}$ \\
\hline Constant & $\begin{array}{l}-4.004^{* * *} \\
{[0.581]}\end{array}$ & $\begin{array}{l}-5.291^{* * * *} \\
{[0.462]} \\
11049\end{array}$ & $\begin{array}{l}-5.611^{* * *} \\
{[0.699]}\end{array}$ & $\begin{array}{l}-7.938 * * * \\
{[0.838]} \\
2570\end{array}$ & $\begin{array}{l}-1.134^{* *} \\
{[0.548]}\end{array}$ & $\begin{array}{l}-5.569 * * * \\
{[0.556]} \\
9579\end{array}$ \\
\hline
\end{tabular}

flexible generalized ordered logit model, using the gologit module written by $\mathrm{Fu}$ (2002). All estimations were carried out using STATA 9.2.

Finally, it might be the case that both early onset of marijuana use and educational success are driven by the same unobservable characteristics such as an individual's personality structure (omitted variables or selection on unobservables). In addition, there is the possibility of reverse causality, i.e., that marijuana consumption is in fact caused by bad school performance. If this is the case, then the estimated coefficients on age of onset will not necessarily have a causal interpretation but will be driven by endogeneity of marijuana use and might be biased and inconsistent. In order to deal with this problem, a frequently used approach in the literature is the use of Instrumental Variables (IVs) (Good IVs have to satisfy two requirements: they have to determine marijuana initiation (often referred to as the strength of the IV) but need to be uncorrelated with educational attainment (often referred to as the validity of the IV). In previous research, both individual-level and local- or regional-level IVs have been used (see French and Popovici, 2011 for a complete discussion) including an individual's self-stated level of religiousness (Register et al., 2001), the timing of smoking and cannabis initiation (Ours and Williams 2009) or state-level policy variables related to drug use (Chatterji, 2006). Unfortunately, there are two drawbacks about the use of IVs: firstly, weak instruments have adverse effects on the sampling properties of the IV estimator and might cause both biased estimates and invalid test statistics. Secondly, there are (up to our knowledge) no instrument validity tests (tests on over-identifying restrictions) available for nonlinear models such as the generalized ordered logit employed in our analysis. Things are complicated further by the fact that I have several potentially endogenous variables, one for each time period of onset of marijuana use. An alternative approach often used in the literature on educational attainment and its determinants is to use (quasi-) natural experiments such as policy reforms (Meyer, 1995; Rosenzweig and Wolpin, 2000; Angrist and Pischke, 2010). In the case of marijuana consumption, a natural experiment might be a change in relevant laws such as the legalization of marijuana consumption in general or for medical purposes (Anderson et al., 2014) for the effect of medical marijuana laws on suicides or Wen et al. (2015) for their effect on consumption of both marijuana and other substances including alcohol for recent research). However, for our research question it is difficult to use such an approach because even if marijuana consumption might be or become legal in a country or state for majors, this is not the case for minors. In addition as Pacula and Sevigny (2014) have argued, the nature of policy reforms regarding marijuana use, among other factors, might limit their usefulness for research and policy recommendations). 
Given the problems with the use of IVs for our research question and the impossibility to use a (quasi-) experimental approach outlined in the footnote, I choose a different approach and try to mitigate the possible omitted variable bias by including available information on respondents that might capture unobserved characteristics driving both marijuana initiation and educational success. Our estimation equation is given by:

$$
\text { Education }_{\mathrm{i}}=\alpha+\delta \text { marijuanaage }_{\mathrm{i}}+\beta \mathrm{X}_{\mathrm{i}}+\varepsilon_{\mathrm{i}}
$$

where, education ${ }_{\mathrm{i}}$ denotes an individual's level of education in three categories (compulsory schooling or less, secondary or tertiary-level education), marijuanaage $_{i}$ is a vector of dummy variables that take the value of 1 if the individual started smoking marijuana during a certain age and $\mathrm{X}_{\mathrm{i}}$ is a vector of control variables.

My regressors of interest in estimation are a vector of dummy variables for the age when respondents started to smoke marijuana (under 15, between 16 and 18 and later in life for the robustness checks). The vector $\mathrm{X}$ contains information on respondent's gender, age their own and their parent's citizenship and the following variables that might capture individual's unobserved characteristics. In order to capture the living conditions of respondents during their childhood, I use a question in the Swiss health survey that asked respondents if they think that they had a happy childhood (measured as their answer to the question "How would you judge your childhood, do you think that your childhood was satisfying or not?" on a scale from 1-5 with 5 being the highest possible level of satisfaction). Montgomery et al. (2008) show the existence of a relationship between parenting styles and drug use. This suggests that including information on satisfaction with one's childhood which is heavily affected by parenting styles, might indeed capture unobserved characteristics that drive both early drug use and educational achievement (of course, there is a number of other factors that might affect educational success such as parental education, parental wealth or ability. Unfortunately, as I are using a health survey, all this information is lacking in the data set but again, satisfaction with childhood might capture at least some of those factors as well).

Lastly, I added a set of dummy variables for the respondent's region of origin (Lake Geneva, Espace Mittelland, Northwestern Switzerland, Zurich, Eastern Switzerland and the Ticino with those living in central Switzerland as the baseline group) and the size of the respondent's place of residence (between 1.000 and 1.999, between 2.000 and 4.999 , between 5.000 and 9.999, between 10.000 and 19.999, between 20.000 and 49.999, between 50.000 and 99.999 and over 100.000 residents with those in villages with $>1.000$ inhabitants as the baseline group) because there might be differences in educational attainment between regions and places of residence.

\section{RESULTS AND DISCUSSION}

The following table presents estimated coefficients from generalized ordered logit regressions for the effect of onset of marijuana use during different periods in youth (under age 15 and between age 16 and 18) on educational outcomes (compulsory schooling or less, secondary or tertiary-level education). Standard errors are given in parentheses. ${ }^{* * *}, * *$ and $*$ denote significance levels of 1 , 5 and $10 \%$, respectively (Results from a model that excludes all those who started to use marijuana after age 18 as a robustness check are provided in Appendix C \}. Results are presented for the entire sample (column I and II), those in general education (column III and IV) and those in vocational education (column V and VI) Table 3.

The estimated coefficients presented in Table 3 are mainly presented for the purpose of giving a first overview of the results. Formal likelihood ratio tests of the generalized ordered logit against the ordered logit model rejected the null hypothesis of equal slope parameters for the entire sample, for those in vocational education and for those in general education. Test statistics are provided at the bottom of Table 3 . Estimation results for the ordered logit models are presented in Table 5 in the Appendix. I will briefly discuss the estimated coefficients before moving on to a more thorough discussion of predicted probabilities to compare the effects of marijuana consumption between those in vocational and those in general education.

In the model for the entire sample, two different parameters are estimated for the probability of having a secondary and a tertiary education, respectively. In this more model, there is no statistically significant estimated coefficient of interest. However, the statistically significant coefficient on a dummy variable for vocational training suggests that there are indeed differences between the educational tracks.

In the model for those in general education, there are some interesting differences: there is a significantly negative coefficient for those who started to use marijuana under age 15 on both the probability of having at least a secondary education and the probability of having a tertiary education but also, more startlingly, a significantly positive coefficient for those who started between age 16 and 18 on the probability of having both a secondary and a tertiary education. Finally, for those in vocational education there is a significantly negative coefficient for those who started to use marijuana under age 15 on the probability of having at least a secondary education but no effect on the probability of having a tertiary education. These results show that there are 
interesting differences between vocational and general education and that there clearly seem to be differences between secondary-level and tertiary-level education that only become visible when estimating the more flexible generalized model. As these results suggest that onset of marijuana use below age 15 leads to lower probabilities of having a secondary general and vocational education and to lower probabilities of having a general tertiary education, it might be the case that the adolescent brain is especially, vulnerable to the possible negative effects of marijuana use in this developmental period, leading to worse mnemonic skills and worse learning abilities and to resulting lower probabilities of finishing secondary general education.

In a next step, I analyze predicted probabilities to give a clearer picture about the differences between those in general and those in vocational education and also about the differences between ages of onset of marijuana use. Predicted probabilities were calculated using the prvalue command in Stata, written by Long and Freese (2005). The following table summarizes predicted probabilities for four different cases: a non-Swiss man, a Swiss man, a non-Swiss woman and a Swiss woman. This baseline person lives in the region "Espace Mittelland" (the region with the biggest population, containing the cantons of Berne, Fribourg, Solothurn, Neuchatel and Jura) in a village with a population between 2,000 and 4,999 inhabitants (the mode category) is 44 years old (the median age in the sample) and considered his or her childhood as "satisfactory" (the second-highest possible rating and again the mode value of responses). The left hand part of the table contains predicted probabilities for those in general education, the central part of the table for those in vocational education. The possible outcomes are again having less than an upper secondary education having an upper secondary education and having a tertiary education. The changes of interest are comparisons between a person who never smoked marijuana or after age 18 (the first row in all four cases), someone who started under age 15 and between age 16 and 18. The right hand part of the table contains the results for z-tests of the null hypothesis of identical predicted probabilities between the two groups which were computed using the method outlined in Long (2009). Here, $* * *, * *$ and $*$ denote significance levels of $1,5 \%$ and $10 \%$, respectively. Confidence intervals for the changes in predicted probabilities were computed using the delta method, also using the Stata program prvalue (Long and Freese 2005). Here, the superscript letter a denotes a significant change in predicted probability between the baseline case of a person who has either never smoked marijuana or only after age 18 and the respective age group of onset (under age 15 and between age 16 and 18) Table 4-6.

In almost all cases, the differences in predicted probabilities between those in general and those in vocational education are statistically significant, suggesting that there are indeed different effects of early onset of marijuana use in the two groups. These effects might be driven by different institutional characteristics of general and vocational education but also by typically different time patterns of completion, especially, for the tertiary-level degrees as graduates of tertiary-level university degrees are usually younger than the graduates of tertiary-level degrees in vocational education.

There are relatively few statistically significant changes in predicted probabilities between those who never smoked marijuana and those who started before age 18. In general education, those who started to use marijuana between age 16 and 18 have a significantly lower predicted probability of having less than an upper secondary education than those who never used it. Somewhat mirroring this result, they also have a significantly higher predicted probability of having a tertiary level education than those who never used the drug. Non-Swiss women who started to use marijuana under age 15 have a significantly higher predicted probability of having less than an upper secondary education than those who never used it. These results are quite similar to the regression results presented before, suggesting that there are almost no harmful effects of early marijuana initiation on educational outcomes. For

Table 4: Predicted probabilities

\begin{tabular}{|c|c|c|c|c|c|c|c|c|c|}
\hline \multirow[b]{2}{*}{ Probabilities } & \multicolumn{3}{|l|}{ General } & \multicolumn{3}{|l|}{ Vocational } & \multicolumn{3}{|l|}{ z-values } \\
\hline & Less than sec. & sec. & tert. & Less than sec. & sec. & tert. & Less than sec. & sec. & tert. \\
\hline Base case male & 0.6560 & 0.1216 & 0.2225 & 0.2019 & 0.6534 & 0.1447 & $48.3736 * * *$ & $82.1887 * * *$ & $9.4678 * * *$ \\
\hline Marijuana under 15 & $0.7630^{\mathrm{a}}$ & 0.1017 & 0.1354 & 0.2881 & 0.5748 & 0.1371 & $56.4710^{* * *}$ & $79.0121^{* * *}$ & -0.2514 \\
\hline Marijuana 16-18 & $0.5657^{\mathrm{a}}$ & 0.1466 & $0.2877^{\mathrm{a}}$ & 0.1873 & $0.6751^{\mathrm{a}}$ & 0.1375 & $38.6389 * * *$ & $75.4997 * * *$ & $16.7971 * * *$ \\
\hline Base case Swiss male & 0.3307 & 0.1962 & 0.4731 & 0.0577 & 0.7072 & 0.2351 & $29.3992 * * *$ & $65.0530 * * *$ & $24.1199 * * *$ \\
\hline Marijuana under 15 & 0.4548 & 0.2157 & 0.3294 & 0.0892 & 0.6867 & 0.2241 & $37.1886^{* * *}$ & $57.8923^{* * *}$ & $11.3358 * * *$ \\
\hline Marijuana 16-18 & $0.2524^{\mathrm{a}}$ & 0.1886 & $0.5590^{\mathrm{a}}$ & 0.0528 & 0.7225 & 0.2247 & $23.2800 * * *$ & $69.0020 * * *$ & $34.0700^{* * * *}$ \\
\hline Base case female & 0.8020 & 0.1034 & 0.0946 & 0.3500 & 0.6046 & 0.6046 & $57.3291^{* * *}$ & $83.1031^{* * *}$ & $-87.9625 * * *$ \\
\hline Marijuana under 15 & $0.8724^{\mathrm{a}}$ & 0.0735 & 0.0541 & 0.4627 & 0.4945 & 0.0428 & $62.0069 * * *$ & $81.3741^{* * *}$ & 2.5299 \\
\hline Marijuana 16-18 & $0.7345^{\mathrm{a}}$ & 0.1369 & $0.1285^{\mathrm{a}}$ & 0.3292 & 0.6279 & 0.0429 & $46.4053^{* * *}$ & $72.1533 * * *$ & $12.9590 * * *$ \\
\hline Base case Swiss female & 0.5121 & 0.2410 & 0.2469 & 0.1153 & 0.8051 & 0.0796 & 40.2001 & $66.7346^{* * *}$ & $19.6510^{* * *}$ \\
\hline Marijuana under 15 & 0.6393 & 0.2086 & 0.1521 & 0.1725 & 0.7524 & 0.0751 & 49.2027 & $67.6859 * * *$ & $10.8587 * * *$ \\
\hline Marijuana 16-18 & $0.4176^{\mathrm{a}}$ & 0.2660 & $0.3164^{\mathrm{a}}$ & 0.1062 & $0.8185^{\mathrm{a}}$ & 0.0753 & 31.9781 & $63.2758^{* * *}$ & $26.2604 * * *$ \\
\hline
\end{tabular}


The Soc. Sci., 14 (10): 346-355, 2019

Appendix

Table 5: Complete descriptive statistics

\begin{tabular}{|c|c|c|c|c|}
\hline Variable & Mean & SD & Min & Max \\
\hline $1=$ marijuana under 15 & 0.0216 & 0.1455 & 0 & 1 \\
\hline 1 = marijuana $16-18$ & 0.0861 & 0.2805 & 0 & 1 \\
\hline $1=$ marijuana over 18 & 0.0828 & 0.2756 & 0 & 1 \\
\hline Age & 43.5496 & 11.3008 & 15 & 64 \\
\hline $1=$ female & 0.5340 & 0.4989 & 0 & 1 \\
\hline Happy childhood & 4.1661 & 0.8742 & 1 & 5 \\
\hline $1=$ swiss & 0.8809 & 0.3239 & 0 & 1 \\
\hline $1=$ father swiss & 0.7729 & 0.4190 & 0 & 1 \\
\hline $1=$ mother swiss & 0.7678 & 0.4223 & 0 & 1 \\
\hline 1 = lives in Lake Geneva region & 0.1543 & 0.3613 & 0 & 1 \\
\hline 1 = lives in Espace Mittelland & 0.2614 & 0.4394 & 0 & 1 \\
\hline $1=$ lives in Northwest & 0.1477 & 0.3548 & 0 & 1 \\
\hline 1 = lives in Zurich & 0.0817 & 0.2740 & 0 & 1 \\
\hline 1 = lives in East & 0.1245 & 0.3302 & 0 & 1 \\
\hline 1 = lives in Ticino & 0.0705 & 0.2560 & 0 & 1 \\
\hline 1 = lives in mun. betw. 1000-1999 inhabitants & 0.1176 & 0.3221 & 0 & 1 \\
\hline 1 = lives in mun. betw. 2000-4999 inhabitants & 0.2216 & 0.4154 & 0 & 1 \\
\hline 1 = lives in mun. betw. 5000-9999 inhabitants & 0.1766 & 0.3813 & 0 & 1 \\
\hline 1 = lives in mun. betw. 10000-19999 inhabitants & 0.1637 & 0.3700 & 0 & 1 \\
\hline 1 = lives in mun. betw. 20000-49999 inhabitants & 0.0904 & 0.2868 & 0 & 1 \\
\hline 1 = lives in mun. betw. 50000-99999 inhabitants & 0.0239 & 0.1527 & 0 & 1 \\
\hline 1 = lives in mun. over 100000 inhabitants & 0.0982 & 0.2976 & 0 & 1 \\
\hline
\end{tabular}

those in vocational education, there are even fewer statistically significant changes. For non-Swiss men and women, those who started to use marijuana between age 16 and 18 have a significantly higher predicted probability of having a secondary education than those who never used it.

While these results might be startling, it should be kept in mind that the Swiss Health Survey contains information on age of onset of marijuana consumption but no information on the intensity or duration of use. It might be the case, for example, that many marijuana users who reported using the drug first between age 16 and 18 just tried the drug once or have used it very rarely which could explain the absence of detrimental effects on educational outcomes. Those who started to use the drug before age 15 , however, might be more prone to become addicted and use the drug more frequently, leading to a negative impact on educational outcomes. There might in fact be very harmful effects on educational outcomes for heavy users of the drug but because of the lack of information in the Swiss Health Survey, I am not able to analyze this possibility in more detail. Lastly, compared to previous studies, the lifetime prevalence of marijuana use in Switzerland is relatively high (Notari et al., 2014) and the country's drug policy is relatively liberal. These two factors taken together might make Switzerland's early consumers a less negatively selected sample than those in other countries and explain the surprising results. However without better data, these explanations cannot be tested.

Finally, as in most empirical research that cannot rely on a quasi-experimental or even experimental approach there is always the possibility that omitted variables might be generating correlations that are the reasons for the observed results here. Again, unfortunately, in the context of research on the effects of drugs on educational outcomes such as the one presented here, it is difficult to think about a quasi-experiment or experiment that could be used for an empirical analysis.

The present study provides an analysis of the impact of the age of onset of marijuana use on educational and labor market outcomes. I focused on different age periods of marijuana use onset as there might be the possibility that initiation during some periods of adolescence is harmful while initiation during other periods is not and also compared the effects for those in general education and those in vocational education as the different institutional settings and time periods might lead to different effects. In addition, I used the flexible generalized ordered logit model that allows to uncover additional interesting differences between secondary and tertiary education.

My results show that there is evidence for harmful effects of early onset of marijuana use, i.e., before age 15. Surprisingly, those who started to use marijuana between age 16 and 18 have significantly higher predicted probabilities of having a secondary and tertiary-level general education than those who never used the drug. It should be kept in mind, however, that those results do not contain any information on the intensity or duration of drug use and it might be the case that most early users in the sample never used the drug intensively or during a long period of time. It should also be kept in mind that those results were not derived using IVs or an experiment but including a variable that might capture unobserved characteristics driving both early drug initiation and 
The Soc. Sci., 14 (10): 346-355, 2019

Table 6: Estimated coefficients, ordered logits

\begin{tabular}{|c|c|c|c|}
\hline \multirow{2}{*}{$\frac{\text { Estimated coefficients }}{1=\text { vocational education }}$} & Entire sample & \multicolumn{2}{|c|}{ General edu. Vocational edu. } \\
\hline & $\begin{array}{l}0.994^{* * *} \\
{[0.058]}\end{array}$ & & \\
\hline $1=$ marijuana under 15 & $\begin{array}{l}-0.246^{*} \\
{[0.147]}\end{array}$ & $\begin{array}{l}-0.485^{*} \\
{[0.280]}\end{array}$ & $\begin{array}{l}-0.223 \\
{[0.167]}\end{array}$ \\
\hline 1 = marijuana 16-18 & $\begin{array}{l}0.095 \\
{[0.076]}\end{array}$ & $\begin{array}{l}0.332 * * \\
{[0.145]}\end{array}$ & $\begin{array}{l}-0.012 \\
{[0.089]}\end{array}$ \\
\hline Age & $\begin{array}{l}0.147 * * * \\
{[0.014]}\end{array}$ & $\begin{array}{l}0.198 * * * \\
{[0.026]}\end{array}$ & $\begin{array}{l}0.114 * * * \\
{[0.016]}\end{array}$ \\
\hline Age squared & $\begin{array}{l}-0.002^{* * *} \\
{[0.000]}\end{array}$ & $\begin{array}{l}-0.002 * * * \\
{[0.000]}\end{array}$ & $\begin{array}{l}-0.001 * * * \\
{[0.000]}\end{array}$ \\
\hline 1 = female & $\begin{array}{l}-0.933^{* * *} \\
{[0.044]}\end{array}$ & $\begin{array}{l}-0.867 * * * \\
{[0.081]}\end{array}$ & $\begin{array}{l}-1.021^{* * *} \\
{[0.051]}\end{array}$ \\
\hline Happy childhood & $\begin{array}{l}0.232 * * * \\
{[0.025]}\end{array}$ & $\begin{array}{l}0.436 * * * \\
{[0.046]}\end{array}$ & $\begin{array}{l}0.240 * * * \\
{[0.028]}\end{array}$ \\
\hline 1 = Swiss citizenship & $\begin{array}{l}1.029 * * * \\
{[0.094]}\end{array}$ & $\begin{array}{l}1.282 * * * \\
{[0.139]}\end{array}$ & $\begin{array}{l}1.304^{* * *} \\
{[0.108]}\end{array}$ \\
\hline 1 = Swiss father & $\begin{array}{l}-0.121 \\
{[0.089]}\end{array}$ & $\begin{array}{l}-0.291^{*} \\
{[0.169]}\end{array}$ & $\begin{array}{l}0.157 \\
{[0.104]}\end{array}$ \\
\hline $1=$ Swiss mother & $\begin{array}{l}-0.178 * * \\
{[0.087]}\end{array}$ & $\begin{array}{l}-0.039 \\
{[0.167]}\end{array}$ & $\begin{array}{l}-0.009 \\
{[0.101]}\end{array}$ \\
\hline $1=$ lives in Lake & $0.232 * * *$ & $0.467 * * *$ & -0.128 \\
\hline Geneva region & {$[0.078]$} & {$[0.143]$} & {$[0.089]$} \\
\hline $\begin{array}{l}1 \text { = lives in Espace } \\
\text { Mittelland }\end{array}$ & $\begin{array}{l}-0.028 \\
{[0.069]}\end{array}$ & $\begin{array}{l}0.072 \\
{[0.135]}\end{array}$ & $\begin{array}{l}-0.106 \\
{[0.077]}\end{array}$ \\
\hline $1=$ lives in Northwest & $\begin{array}{l}0.129 * \\
{[0.078]}\end{array}$ & $\begin{array}{l}0.443^{* * *} \\
{[0.157]}\end{array}$ & $\begin{array}{l}0.151^{*} \\
{[0.088]}\end{array}$ \\
\hline $1=$ lives in Zurich & $\begin{array}{l}0.074 \\
{[0.092]}\end{array}$ & $\begin{array}{l}0.205 \\
{[0.186]}\end{array}$ & $\begin{array}{l}0.218^{* *} \\
{[0.104]}\end{array}$ \\
\hline 1 = lives in East & $\begin{array}{l}-0.06 \\
{[0.079]}\end{array}$ & $\begin{array}{l}-0.058 \\
{[0.167]}\end{array}$ & $\begin{array}{l}0.063 \\
{[0.088]}\end{array}$ \\
\hline $1=$ lives in Ticino & $\begin{array}{l}-0.169^{*} \\
{[0.098]}\end{array}$ & $\begin{array}{l}0.13 \\
{[0.162]}\end{array}$ & $\begin{array}{l}-0.418 * * * \\
{[0.113]}\end{array}$ \\
\hline 1 = lives in mun. betw. & -0.002 & -0.155 & 0.027 \\
\hline 1000-1999 inhabitants & {$[0.088]$} & {$[0.170]$} & {$[0.099]$} \\
\hline $\begin{array}{l}1=\text { lives in mun. betw. } \\
2000-4999 \text { inhabitants }\end{array}$ & $\begin{array}{l}0.055 \\
{[0.079]}\end{array}$ & $\begin{array}{l}-0.079 \\
{[0.152]}\end{array}$ & $\begin{array}{l}0.043 \\
{[0.088]}\end{array}$ \\
\hline $\begin{array}{l}1=\text { lives in mun. betw. } \\
5000-9999 \text { inhabitants }\end{array}$ & $\begin{array}{l}0.209 * * \\
{[0.083]}\end{array}$ & $\begin{array}{l}0.13 \\
{[0.160]}\end{array}$ & $\begin{array}{l}0.239 * * \\
{[0.093]}\end{array}$ \\
\hline 1 = lives in mun. betw. & $0.224^{* * *}$ & $0.376^{* *}$ & $0.158^{*}$ \\
\hline 10000-19999 inhabitants & [0.084] & [0.162] & [0.095] \\
\hline $\begin{array}{l}1 \text { = lives in mun. betw. } \\
20000-49999 \text { inhabitants }\end{array}$ & $\begin{array}{l}0.470 * * * \\
{[0.096]}\end{array}$ & $\begin{array}{l}0.510 * * * \\
{[0.172]}\end{array}$ & $\begin{array}{l}0.209^{*} \\
{[0.110]}\end{array}$ \\
\hline $1=$ lives in mun. betw. & $0.471^{* * *}$ & $0.530 *$ & 0.237 \\
\hline 50000-99999 inhabitants & {$[0.155]$} & {$[0.278]$} & {$[0.177]$} \\
\hline 1 = lives in mun. over & $0.713^{* * *}$ & $0.935 * * *$ & $0.256 * *$ \\
\hline 100000 inhabitants & [0.099] & {$[0.176]$} & {$[0.115]$} \\
\hline$\underline{\mathrm{n}}$ & 11049 & 2570 & 9579 \\
\hline
\end{tabular}

educational attainment. Therefore, it is not clear if these results are due to a causal effect. However, they have shown some interesting results and differences between general and vocational education that could be analyzed using more sophisticated empirical methods in the future.

\section{CONCLUSION}

Future research could include an analysis of the effects for differences in intensity or duration of past marijuana use. It would be desirable to include such questions in health surveys in order to enable researchers to carry out such an analysis. Finally, while natural experiments or quasi-experiments might provide more convincing statistical evidence on causal effects, it is very difficult to think of such an experiment that might provide an opportunity to analyze the effects of the age of onset of marijuana use of minors on educational outcomes.

\section{ACKNOWLEDGEMENT}

This researcher is based on research from my $\mathrm{PhD}$ thesis which was partly funded by the Swiss Federal Office for Professional Education and Technology through its "Leading House on the Economics of Education: Firm Behaviour and Training Policies”. I also wish to thank the German Academic Exchange Service (DAAD) for financial support through a scholarship and the Institute for Research on Labor and Employment at the University of California, Berkeley, for its hospitality. Olga Reimann, Franziska Schoch and Miru Song have provided excellent research assistance.

\section{REFERENCES}

Allison, P.D., 1999. Comparing logit and probit coefficients across groups. Socio. Meth. Res., 28: 186-208.

Anderson, D.M., D.I. Rees and J.J. Sabia, 2014. Medical marijuana laws and suicides by gender and age. Am. J. Publ. Health, 104: 2369-2376.

Angrist, J.D. and J.S. Pischke, 2010. The credibility revolution in empirical economics: How better research design is taking the con out of econometrics. J. Econ. Perspect., 24: 3-30.

Anonymoous, 2015. European school survey project on alcohol and other drugs. European Monitoring Centre for Drugs and Drug Addiction (EMCDDA), Lisbon, Portugal.

Bessey, D., 2010. Educational investment of youths: Empirical and experimental evidence. Ph.D Thesis, University of Zurich, Zurich, Switzerland.

Chatterji, P., 2006. Illicit drug use and educational attainment. Health Econ., 15: 489-511.

French, M.T. and I. Popovici, 2011. That instrument is lousy! In search of agreement when using instrumental variables estimation in substance use research. Health Econ., 20: 127-146.

Fu, V.K., 2002. GOLOGIT: Stata module to estimate generalized ordered logit models. Stat. Software Compon., Vol. 1,

Grant, I., R. Gonzalez, C.L. Carey, L. Natarajan and T. Wolfson, 2003. Non-acute (residual) neuro cognitive effects of cannabis use: A meta-analytic study. J. Intl. Neuropsychol. Soc., 9: 679-689.

Hungerford, T. and G. Solon, 1987. Sheepskin effects in the returns to education. Rev. Econ. Stat., 69: 175-177. 
Long, J.S. and J. Freese, 2005. Regression Models for Categorical Outcomes using Stata. Stata Press, College Station, Texas,.

Long, J.S., 2009. Group comparisons in logit and probit using predicted probabilities. Master Thesis, Department of Sociology, University of Indiana, Indiana.

McCaffrey, D.F., R.L. Pacula, B. Han and P. Ellickson, 2010. Marijuana use and high school dropout: The influence of unobservables. Health Econ., 19: 1281-1299.

Meyer, B.D., 1995. Natural and quasi-experiments in economics. J. Bus. Econ. Stat., 13: 151-161.

Montgomery, C., C. Montgomery, J.E. Fisk, C. Montgomery and J.E. Fisk et al., 2008. The effects of perceived parenting style on the propensity for illicit drug use: The importance of parental warmth and control. Drug Alcohol Rev., 27: 640-649.

Notari, L., 2014. Zusammen fassende ergebnisse der schweizerischen gesundheitsbefragungen 2012, 2007, 2002, 1997 und 1992 hinsichtlich des Konsums von Tabak, Alkohol, Medikamenten und illegalen Drogen. Addiction info Suisse, Lausanne, Switzerland.
Ours, J.C.V. and J. Williams, 2009. Why parents worry: Initiation into cannabis use by youth and their educational attainment. J. Health Econ., 28: 132-142.

Pacula, R.L. and E.L. Sevigny, 2014. Marijuana liberalization policies: Why we can't learn much from policy still in motion. J. Policy Anal. Manage., 33: 212-221.

Pacula, R.L., K.E. Ross and J. Ringel, 2003. Does marijuana use impair human capital formation? NBER Working Paper (No. w9963). National Bureau of Economic Research, Massachusetts. http://www.nber.org/papers/w9963

Register, C.A., D.R. Williams and P.W. Grimes, 2001. Adolescent drug use and educational attainment. Educ. Econ., 9: 1-18.

Roebuck, M.C., M.T. French and M.L. Dennis, 2004. Adolescent marijuana use and school attendance. Econ. Educ. Rev., 23: 133-141.

Rosenzweig, M.R. and K.I. Wolpin, 2000. Natural natural experiments in economics. J. Econ. Lit., 38: 827-874.

Wen, H., J.M. Hockenberry and J.R. Cummings, 2015. The effect of medical marijuana laws on adolescent and adult use of marijuana, alcohol and other substances. J. Health Econ., 42: 64-80. 